\title{
Introduction: The nature of political opposition in contemporary electoral democracies and autocracies
}

\author{
Ludger Helms ${ }^{1}$
}

Accepted: 8 February 2021 / Published online: 21 April 2021

(C) The Author(s) 2021

\begin{abstract}
At the level of regime typologies, the uncertain status and inherent weakness of the opposition mark defining features of regimes beyond liberal democracy. However, even the performance and evolution of the latter tend to be shaped by oppositions and the regime's approach to dealing with them. This article offers a bird's-eye view of political oppositions in contemporary electoral democracies and competitive autocracies. It focuses on patterns of strategic choices and behavior by both governments and oppositions. That endeavor forms part of a larger joint venture seeking to give center stage to those actors living in the shadows of increasingly unscrupulous power-holders.
\end{abstract}

Keywords Competitive autocracies · Electoral democracies · Political opposition · Strategies

\section{Political oppositions beyond liberal democracy: conceptual issues}

Democracy is as much about opposition as it is about government. Trantidis (2017) even suggests that government contestability by an effective opposition should be a constitutive part of any serious definition of democracy. However, opposition is not just a defining feature of democratic governance but of politics more generally. Indeed, to some extent even many oppositions operating in autocratic contexts tend to display some features that are reminiscent of democratic politics, or democratic opposition for that matter. After all, the conviction driving oppositions in fundamentally different types of regime, "that the world can be other than it is (...) that situations can be countered, outcomes altered, people's lives changed through individual and collective action" (Keane 2009: 853), is what democracy is ultimately all about.

It took international political science long to recognize the value of studying political opposition across democratic and autocratic regimes. Dahl's seminal

Ludger Helms

ludger.helms@uibk.ac.at

1 University of Innsbruck, Universitätsstraße 15, 6020 Innsbruck, Austria 
volume of 1966, which remained the unchallenged point of reference in the field for decades, famously focused on political oppositions in Western democracies (Dahl 1966). The realization that there can be genuine political opposition in different types of democratic and autocratic regimes did not break much before the turn of the century. A classic paper from this period is the one by Jean Blondel. As Blondel contended, "opposition is a "dependent" concept .... This means that the character of the opposition is tied to the character of the government. The notion of opposition is thus, so to speak, parasitic on ideas of government, of rule, of authority. (...) Yet the recognition that there is a dependence of opposition on government does not mean that variations in types and forms of opposition should not be looked into" (Blondel 1997: 463).

Given its established status as a subject of international political research, it is curious how elusive, and contested, terminological and conceptual boundaries in this field have remained. While there is much consensus about the quality of government and opposition as any political system's fundamental "binary code" (Luhmann 1989), it is far from universally acknowledged that what is not government in politics is necessarily "opposition." Some reservations even concern the parliamentary arena in established democratic regimes. Specifically, some scholars have questioned the silent equation of non-government parties and opposition parties in parliament, suggesting that only those non-governing parties in parliament that seek to win governmental office and are viable coalition partners are genuine opposition parties (see, e.g., Niclauss 1995: 50). Such a position surely can be justified. That said, ever since Sartori's major work on parties and party systems (Sartori 1976), even outright "anti-system parties" have widely been members of the larger family of opposition parties (see also Norton 2008: 237-238). Recent re-conceptualizations of anti-system parties have been driven specifically by the growing realization that, in many contexts, parties sharing some anti-system properties have effectively become institutionalized and integrated members of democratic political systems (Zulianello 2018).

As soon as one moves from here to studying political oppositions in regimes beyond liberal democracy, established terms tend to lose their familiar meanings. For example, anti-system opposition parties that we can find in many autocratic regimes as well are equivalents of anti-system opposition parties in democratic contexts in little more than name. While anti-system parties in democratic systems usually pursue agendas leading away from full-blown liberal democracy, anti-system parties in autocratic regimes are often, though not necessarily or always, committed to the ideals of democratic governance.

Another issue of major conceptual and empirical relevance concerns the status of party-based opposition, and other forms of opposition in different types of political regime. Again, there has been a major debate if or to what extent actors and activities from beyond the parliamentary arena should be considered to form part of "the opposition" at all. It is worth noting that opposition and resistance or dissidence have distinctly different roots in the History of Political Thought (see Jäger 1978: 471), which has however not hindered contemporary scholars of International Political Theory to refer to opposition and dissidence as two forms of resistance (see Daase and Deitelhoff 2019). Moreover, the distinction between opposition and 
dissidence, or oppositionists and dissidents for that matter, has not just concerned scholars but practitioners, as well. As Szulecki (2019: 22-28) has pointed out in the context of revisiting the politics of dissent in Communist Central Europe, there is a wealth of different notions of opposition, in relation to dissidence; while some understandings consider opposition and dissent as (near) synonyms, others carry genuinely different political meanings. For all that, echoing a passionate call by Brack and Weinblum (2011), the overall trend in more recent international research has been clearly towards more encompassing notions of political opposition, extending from party politics within and beyond the parliamentary arena to manifestations of protest and dissent.

Empirically, there are distinct patterns of party/parliamentary and non-parliamentary forms of opposition even within a given family of regimes. For example, France has a longstanding tradition of "street politics," which is conspicuous and exceptional by West European standards, and reflects both an institutionalized weakness of the parliamentary opposition in the Fifth French Republic and a particular arrogance of French executive leadership (Mény 2008: 103). The major Yellow Vests movement marked just the latest phenomenon of its kind (Grossman 2019).

That said, some patterns are more generally related to the type of government or political regime. Specifically, regimes differ fundamentally in the extent to which the electoral and parliamentary arenas provide space for voicing opposition and dissent to power-holders. Generally, the more a given regime leans towards a closed autocracy - the fourth type of regime, alongside electoral autocracies, electoral democracies and liberal democracies, distinguished by Lührmann et al. (2018: 3, Table. 1) - the less likely are the systematic functions of political opposition to be concentrated in the hands of political parties. The "other actors" include individual prominent dissidents, critical media as well as, and not least, participants in mass protests.

One of the most fascinating, and important, features of oppositional politics concerns the relationship between those different actors of the opposition. Overall, the relations between different actors forming part of the opposition have grown more complex and diverse in many regimes, including consolidated democratic systems. While historically parties and movements have been closely intertwined with parties operating as the parliamentary agent of the larger movement (see Maguire 1995), the recent past has witnessed a growing separation of oppositional parties and citizen groups in many Western democracies (see Butzlaff and Deflorian 2019). However, this applies more to recent developments at the micro-level of party-group (non-)relations in some of the advanced democracies than to other contexts. At the meso- and macro-levels of competitive authoritarian regimes, where possible regime transitions are usually played out, parties have largely reserved their reputation as more or less indispensable agents, equipping would-be leaders with the institutional and organizational resources needed for exerting large-scale political leadership. Belarus, where the protagonists of the mass protests surrounding the presidential election of 2020 and its aftermath eventually decided to form a new party, "Together," marks a recent case in point (Ivanova 2020). Still, other recent evidence, from Russia and beyond, warns against taking the existence of anything like a natural correlation between mounting protests and increased support for the regime's challengers and opposition parties for granted (Tertytchnaya 2020). 


\section{Oppositional politics in the era of "personalized authoritarian politics"}

Recent scholarly debate on the global state of democratic and autocratic government has revolved around the rise of "a third wave of autocratization" (Lührmann and Lindberg 2019). What marks a distinct stage in the historical evolution of political regimes for some, with conspicuously many contemporary autocratization episodes affecting democracies (ibid: 1103-4), amounts to little more than a questionable set of indicators for others (Skaaning 2020). Yet such issues of conceptualization and measurement apart, there is a wide consensus on some of the defining features of the current and recent global transformations of political regimes. These include in particular notions of "executive aggrandizement" (Bermeo 2016: 10) and "personalized authoritarian politics" (Kendall-Taylor et al. 2017: 14). Indeed, the executive-centeredness of public attention in the current global state of public affairs is considerably more pronounced than at any time in recent decades (see Andeweg et al. 2020).

This is not necessarily bad news for potential challengers. Resent research suggests that "by increasing the degree of personalization, dictators reduce their vulnerability to insider challenges while at the same time increasing their vulnerability to outsider challenges" (Grundholm 2020: 797). However, in regimes that are not run by outright dictators but autocratic leaders that have been elected and enjoy the support of a sizeable proportion of the population, such as Erdoğan in Turkey or Putin in Russia, there are more particular challenges of personalized rule. As a recent study on the "Erdoğanziation" of Turkish politics suggests, oppositional strategies centering on attacking and disavowing the man at the top personally may backfire. "Contrary to what the opposition leaders aimed to achieve, the negative agenda antagonized Erdoğan supporters and consolidated their in-group identity" (Selçuk et al. 2019: 559; see also Aras and Helms 2021). Thus, overall, personalized competitive autocratic regimes are certainly not generally a more favorable playing ground for the opposition than other forms of autocratic or quasi-autocratic rule.

This symposium seeks to give center stage to the undervalued and understudied actors of the political opposition. It launches an agenda dedicated to providing consequently opposition-focused - and thus distinctly complementary-assessments of typically leader-centered electoral democracies and autocracies. While the case studies gathered for this symposium focus on European countries (with Turkey and Russia marking border cases), the next section of this introductory piece seeks to capture the nature of political oppositions beyond liberal democracy on a larger scale, accounting for issues and features observed both in and outside of Europe.

\section{Political oppositions beyond liberal democracy: Some empirical features and patterns}

The group of "political regimes beyond liberal democracy" that do not fall in the residual category of closed autocracies is immensely complex and diverse. Nevertheless, there are certain shared features, some of which are of immediate relevance 
in our context. As to elections and election-induced uncertainty, what can be largely taken for granted in electoral democracies is true for competitive authoritarian regimes or electoral autocracies, as well. "Even though democratic institutions may be badly flawed, both authoritarian incumbents and their opponents must take them seriously" (Levitsky and Way 2002: 54), and notwithstanding the uneven playing field between government and opposition, incumbents can still lose elections. Arguably the single most important lesson emerging from an opposition-centered exploration into the world beyond liberal democracy is that even seemingly "primitive" competitive autocratic regimes (as well as closed autocracies) can be home to complex strategies of both incumbent and opposition actors (see Schedler 2013).

First, the strategic goal of governments in electoral autocracies cannot be reasonably reduced to simply banning any political oppositions altogether. Actually, the recent experience of Hong Kong, where Chinese power-holders not only banned the opposition from the streets but more recently also expelled defiant opposition members from parliament, marks an exception rather than the rule. As Armstrong et al. (2020: 2) have observed, “in many of today's autocracies ... regime leaders divide the political opposition into a systemic component that is allowed to participate in official politics and a non-systemic component that is excluded from elections, spoils distribution, and policymaking." In some settings, the "systemic" opposition is called the "loyal" or "official" opposition. Excluded groups meanwhile are sometimes referred to as the "radical opposition" or the "unrecognized opposition." Prominent examples stretch from Suharto's Indonesia and South Africa under apartheid to the Arab world. More specifically, autocratic power-holders can have a strong interest in allowing the existence of certain opposition groups as part of their legitimation or survival strategies (see Magaloni and Kricheli 2010: 126-128). This may include the creation of "Ersatz" opposition parties to create the appearance of multiparty competition (see March 2009).

Second, not all opposition parties in electoral autocracies are invariably committed to overthrowing the regime. As Dettman notes, "the literature on democratization has tended to assume a fixed regime-changing or democratizing goal of opposition parties" (Dettman 2018: 33), but non-government/opposition parties "can be pro-regime, showing willingness to join the ruling government and showing little outward evidence of pursuing regime change" (ibid: 36). Actually, this does not apply to opposition parties only; even social and protest movements, whose very raison d'être is generally believed to be about generating change, are not always progressive forces advancing democratization (see, e.g., Albrecht 2005; Kitirianglarp and Hewison 2009).

Third, opposition parties, actors or groups that are anti-government and antiregime may still use fundamentally different strategies. This may include the formation of pre-election alliances and post-election coalitions, as well as organizing electoral boycotts. While there are few, if any, hard-and-fast rules of how exactly to deal with particular challenges, research on political oppositions in Venezuela and Colombia suggests that it is worthwhile for the opposition to make use of the institutional leverage a regime provides them with, rather than to rely primarily or exclusively on radical extra-institutional strategies (Gamboa 2017). 
Cooperation and coalition-building between opposition actors have increasingly become an issue in its own right. While conventional wisdom holds that "there is no coalition in opposition" in democratic party government contexts, collective opposition strategies are notably widespread in autocratic regimes. Pre-electoral coalitions existed in a quarter of all authoritarian elections held in the first decade of the twenty-first century (Gandhi and Reuter 2013: 140; see also Dettman 2018: 57). Electoral coalitions among different opposition parties have proven successful in unseating incumbents from the Ukraine to the Philippines and Kenya, as well as in some cosmopolitan cities like Istanbul and Budapest. The most impressive recent example at the national level, however, relates to Malaysia, where the oppositional coalition Pakatan Harapan (or Hope Alliance) won the federal elections in 2018 for the first time in the history of the country (see Ufen 2020).

Systematic comparative research on electoral coalitions suggests that, other things being equal, the willingness of the opposition to form pre-electoral coalitions tends to increase when opposition actors do not expect the incumbent regime to win, that is, when change seems likely or at least possible. What is also worth noting is that coalitions that include previous regime insiders who defected to the opposition have often been more successful (Hauser 2019). Partly contrary to this, recent research on Morocco suggests that the recent increase in collaboration between the oppositional Left and Islamist movements was favored precisely by "the excluded nature of these actors and their lack of electoral interests" (Cassani 2020: 1183). Other research has pointed out that electoral successes and defeats of opposition coalitions depend strongly on the willingness of voters to support the coalescing strategies of party leaders, policies and policy preferences (Gandhi and Ong 2019) as well as psychological characteristics of individuals (Young 2020), which matter in autocratic contexts just as much as they usually do in democracies. Balancing these diverging preferences is at the heart of the observed dilemmas faced by systemic and non-systemic oppositions seeking cooperation with each other (see Armstrong et al. 2020).

Opposition boycotts mark an alternative election-related strategy of opposition parties that has been particularly prominent in Africa, but by no means strictly confined to that region. Most early work on boycotts suggests that opposition parties will boycott in particular when they believe they will do poorly in a given election, that is, essentially to "save face." However, as a recent major study on political oppositions in Arab regimes contends, "the strategies adopted by opposition groups during and after authoritarian elections are driven by perceptions of regime strength and stability, extending well beyond election-related considerations, such as the freeness and fairness of the election and an opposition group's prospects of victory at the polls" (Buttorff 2019: 7).

While boycotts are in one sense a non-violent tactic that opposition parties may adopt to gain concessions from authoritarian powers, they can also be part of a larger strategy to inspire post-election protests that may ultimately undermine the stability and authority of a given regime. Apart from elusive losses of reputation, boycotts tend to produce lower turnout, "which can make the incumbent vulnerable to future criticisms and electoral challenges" and thus "may open up the electoral playing field further in the long term, allowing for future opposition victories" (Hauser 2019: 21). Importantly, however, as Dettman (2018: 256) points out, even 
"opposition parties that win power by unseating the incumbent through elections face the choice of implementing democratizing reforms, or preserving the advantages of authoritarian incumbency" (see also Wahman 2014).

What seems important to add under the heading of strategic agency of opposition actors in competitive autocratic regimes is that oppositional strategies are clearly not limited to the electoral or parliamentary arenas. As Bedford and Vinatier (2019) remind us in their carefully conceptualized study of "oppositional ghettos" and "resistance models," electoral activities can equally well focus on the media, lobbying or educational activities. As the authors further contend, a common characteristic of these different "models of resistance" is that challenging the current authorities' hegemony often takes priority over achieving any long-term goals that may be impossible to realize. In that sense, "the opposition actors' work becomes "oppositional for the sake of it"” (ibid: 707).

Fourth, regime types do matter even in authoritarian contexts. Overall, while in the family of democratic regimes it is generally parliamentary systems that offer the most favorable opportunity structures to opposition parties (Helms 2008), the chances for political oppositions in autocratic contexts to leave their mark on the wider political process often seem to be better in presidential than in other types of autocratic regime. Opposition parties can nominate a widely popular individual for election, even if they struggle to appeal to voters in legislative elections (Dettman 2018: 75). Also, electoral coalitions have been particularly successful in presidential autocracies (Gandhi and Ong 2019: 949-950). Other differences that exist are more difficult to assess in terms of failure and success. For example, boycotts have been more frequent in presidential elections, as Hauser (2019: 20) suggests, though this says little about the ultimate successes of opposition forces to oust incumbent autocrats.

Fifth, regime-related legacies matter. There is reason to believe that it makes much of a difference if a regime turns into an electoral autocracy from a formerly closed autocracy, or from a more democratic type of regime. This is because dictatorships have distinct legacies and tend to cast a particular shadow on political oppositions and their tactical and strategic choices (see Bermeo 1992: 273-274; for a more recent example, see also Conduit and Akbarzadeh 2019: 8). Importantly, those legacies do not have to be of a toxic nature. Rather, the hurtful memory of massacres under the previous regime may drive new oppositions to pursue mainly peaceful strategies.

\section{The articles and key findings of this symposium}

The cases gathered for this symposium share one major common feature with each other: With few exceptions, all major countries covered here were identified as prime examples of autocratization in the latest V-Dem Democracy Report of 2020 which focuses on the developments of the past decade. The single most important exception concerns Russia, where the democratic rollback set in a full decade earlier, with no significant reverses recorded ever since. Another thing that unites these articles, or their authors for that matter, is the belief that the 
institutional parameters characterizing a given regime tend to shape oppositional behavior and performance to a considerable extent. After all, virtually all agency in politics is "structured agency," and all strategies-that guide the actions of political actors in opposition and elsewhere-are little else but ideas for, or manifestations of, rational behavior seeking to exploit institutional (and other contextual) opportunities to advance the achievement of particular goals (Helms 2014). However, this does not imply that institutions would ever actually determine the behavior and fate of actors pursuing competing missions in complex environments. Indeed, the articles of this symposium provide fresh evidence for the limits of purely institutional explanations of oppositional performance.

Further, in line with the established tradition of small-n political research, which is at its best when it comes to identifying new causalities and developing hypotheses for future research, rather than testing sweeping theories, the majority of articles proceeds inductively in capturing key features of the politics of opposition in these countries. In a field that has been infamous for the striking immunity of its key subjects to grand-scale theorizing (see De Giorgi and Ilonszki 2018: 244), anything else would seem unreasonable and misplaced.

In his article on political opposition in Putin's Russia, Andrey Semenov offers a succinct assessment of the complex evolutionary dynamics of the past two decades. The particular focus of this piece is on the regime's continuous efforts to deal with its challengers by operating a sophisticated system of organizational control, and the oppositions' desperate attempts of coping with this. Focusing on Erdoğan's Turkey, Bülent Aras and Ludger Helms show how the attempts of a longstanding power-holder to tighten his grip, and institutionalize his predominance, may generate inverse effects by creating unintended incentives for opposition actors to pool their resources.

Both articles provide new evidence for the well-founded assumption that longstanding political strongmen and their supporters can give opponents and oppositions a particularly hard time. Still, their findings are not at odds with the observation that "personalizing autocrats" are marked by a particular vulnerability to challengers and challenges from beyond their close environment. Overall, recent opposition-related developments in Turkey have been considerably more heartening than developments in Russia. This finding is in line with other recent research suggesting that-notwithstanding apparent parallels between "Erdoğanism" and "Putinism"- - for the time being at least, Erdoğan's Turkey and Putin's Russia, remain distinctly different regimes (see Bechev and Kınıklığlu 2020).

Two comparative analyses follow these two single-case studies of the symposium. Authored by Gabriella Ilonszki and Agnieszka Dudzińska, the first one of these assesses oppositional behavior in Hungary and Poland-two "post-communist" EU member states. Finally, Claudia Laštro and Florian Bieber provide a wideranging comparative assessment of the political opposition in the three competitive authoritarian regimes of the Western Balkans, i.e. Montenegro, Serbia and North Macedonia.

Echoing the lessons drawn by Aras and Helms, the key findings of these two papers point to the limits of purely institutional (as well as cultural and historical) explanations of political opposition. Neither institutional similarities nor shared 
historical legacies determine the nature of political opposition. There is no single pattern of opposition politics valid across these samples of cases, and no determining effect of contextual parameters. Political agency (of both governments and oppositions) shapes the patterns of oppositional power and performance to a significant extent. These findings concur with other recent research on the varied performance of Central and Eastern European political oppositions during the Corona pandemic (see Guasti 2020).

For oppositions in political regimes beyond liberal democracy, the central proposition emerging from this symposium is that their actions can make all the difference.

Acknowledgments I am immensely grateful to the anonymous reviewers and the editors of this journal, in particular Daniel Stockemer, for their most valuable constructive critique of an earlier draft of this paper and this Symposium more generally. Further, I gratefully acknowledge the generous support by Agnieszka Dudzińska and David M. Willumsen who commented on a previous draft of this intro piece. Finally, I would like to thank Sebastian Dettman for kindly sharing his unpublished Cornell PhD dissertation, and the inspiration provided by this major work. Needless to say, the usual disclaimer applies.

Funding Open Access funding provided by Universität Innsbruck.

Open Access This article is licensed under a Creative Commons Attribution 4.0 International License, which permits use, sharing, adaptation, distribution and reproduction in any medium or format, as long as you give appropriate credit to the original author(s) and the source, provide a link to the Creative Commons licence, and indicate if changes were made. The images or other third party material in this article are included in the article's Creative Commons licence, unless indicated otherwise in a credit line to the material. If material is not included in the article's Creative Commons licence and your intended use is not permitted by statutory regulation or exceeds the permitted use, you will need to obtain permission directly from the copyright holder. To view a copy of this licence, visit http://creativecommons.org/licen ses/by/4.0/.

\section{References}

Albrecht, H. 2005. How can opposition support authoritarianism? Lessons from Egypt. Democratization 12 (3): 378-397.

Andeweg, R.B., R. Elgie, L. Helms, J. Kaarbo, and F. Müller-Rommel. 2020. The political executive returns: Re-empowerment and rediscovery. In The Oxford handbook of political executives, ed. R.B. Andeweg, et al., 1-22. Oxford: Oxford University Press.

Aras, B., and L. Helms. 2021. The Limits of institutionalizing predominance: Understanding the emergence of Turkey's new opposition. European Political Science. https://doi.org/10.1057/ s41304-021-00327-9.

Armstrong, D., O.J. Reuter, and G.B. Robertson. 2020. Getting the opposition together: Protest coordination in authoritarian regimes. Post-Soviet Affairs 36 (1): 1-19.

Bedford, S., and L. Vinatier. 2019. Resisting the irresistible: 'Failed opposition' in Azerbaijan and Belarus revisited. Government and Opposition 54 (4): 686-714.

Bechev, D. and S. Kınıklığlu, 2020. Turkey and Russia: No birds of the same feather. SWP Comment No. 24, Berlin: Center for Applied Turkish Studies.

Bermeo, N. 1992. Democracy and the lessons of dictatorship. Comparative Politics 24 (3): 273-291.

Bermeo, N. 2016. On democratic backsliding. Journal of Democracy 27 (1): 5-19.

Blondel, J. 1997. Political opposition in the contemporary world. Government and Opposition 32 (4): $462-486$.

Brack, N., and S. Weinblum. 2011. "Political opposition": Towards a renewed research agenda. Interdisciplinary Political Studies 1 (1): 69-79. 
Buttorff, G.J. 2019. Authoritarian elections and opposition groups in the Arab World. Basingstoke: Palgrave.

Butzlaff, F., and M. Deflorian. 2019. Die neue alltagspolitische Opposition (APO)? Wie Parteien und Nischenbewegungen auseinanderdriften. INDES 3: 43-54.

Cassani, A. 2020. Cross-ideological coalitions under authoritarian regimes: Islamist-left collaboration among Morocco's excluded opposition. Democratization 27 (7): 1183-1201.

Conduit, D., and S. Akbarzadeh. 2019. Contentious politics and Middle Eastern oppositions after the uprisings. In New oppositions in the Middle East, ed. D. Conduit and S. Akbarzadeh, 1-14. Basingstoke: Palgrave Macmillan.

Daase, C., and N. Deitelhoff. 2019. Opposition and dissidence: Two modes of resistance against international rule. Journal of International Political Theory 15 (1): 11-30.

Dahl, R.A., ed. 1966. Political oppositions in Western democracies. New Haven: Yale University Press.

De Giorgi, E., and G. Ilonskzki. 2018. Conclusions. In Opposition parties in European legislatures: Conflict or consensus?, ed. E. De Giorgi and G. Ilonszki, 229-246. London: Routledge.

Dettman, S. 2018. Dilemmas of opposition: Building parties and coalitions in authoritarian regimes. Ph.D.-Dissertation, Cornell University.

Gamboa, L. 2017. Opposition at the margins: Strategies against the erosion of democracy in Colombia and Venezuela. Comparative Politics 49 (4): 457-477.

Gandhi, J., and O.J. Reuter. 2013. The incentives for pre-electoral coalitions in non-democratic elections. Democratization 20 (1): 137-159.

Gandhi, J., and E. Ong. 2019. Committed or conditional democrats? Opposition dynamics in electoral autocracies. American Journal of Political Science 63 (4): 948-963.

Geddes, B., J. Wright, and E. Frantz. 2018. How dictatorships work. Cambridge: Cambridge University Press.

Grossman, E. 2019. France's yellow vests-symptom of a chronic disease. Political Insight 10 (1): 30-34.

Grundholm, A.T. 2020. Taking it personal? Investigating regime personalization as an autocratic survival strategy. Democratization 27 (5): 797-815.

Guasti, P. 2020. The impact of the COVID-19 pandemic in central and Eastern Europe. Democratic Theory 7 (2): 47-60.

Hauser, M. 2019. Electoral strategies under authoritarianism: Evidence from the former Soviet Union. Lanham: Lexington/Lynne Rienner.

Helms, L. 2008. Studying parliamentary opposition in old and new democracies: Issues and perspectives. Journal of Legislative Studies 14 (1-2): 6-19.

Helms, L. 2014. Institutional analysis. In The Oxford Handbook of political leadership, ed. P.T. Hart and R.A.W. Rhodes, 195-209. Oxford: Oxford University Press.

Ivanova, P. 2020. Belarus opposition leaders to create new political party, The Independent, 1 September 2020, https://www.independent.co.uk/news/world/europe/belarus-protests-opposition-electionmaria-kolesnikova-lukashenko-together-a9697916.htm

Jäger, W. 1978. Opposition. In Geschichtliche Grundbegriffe, vol. 4, ed. O. Brunner, et al., 496-517. Stuttgart: Klett-Cotta.

Keane, J. 2009. The life and death of democracy. New York: W.W. Norton \& Co.

Kendall-Taylor, A., E. Frantz, and J. Wright. 2017. The global rise of personalized politics: It's not just dictators anymore. The Washington Quarterly 40 (1): 7-19.

Kitirianglarp, K., and K. Hewison. 2009. Social movements and political opposition in contemporary Thailand. The Pacific Review 22 (4): 451-477.

Levitsky, S., and L.A. Way. 2002. Elections without democracy: The rise of competitive authoritarianism. Journal of Democracy 13 (2): 51-65.

Luhmann, N. 1989. Theorie der politischen Opposition. Zeitschrift Für Politik 36 (1): 13-26.

Lührmann, A., and S.I. Lindberg. 2019. A third wave of autocratization is here: What is new about it? Democratization 26 (7): 1095-1113.

Lührmann, A., M. Tannenberg, and S. Lindberg. 2018. Regimes of the World (RoW): Opening new avenues for the comparative study of political regimes. Politics and Governance 6 (1): 60-77.

Magaloni, B., and R. Kricheli. 2010. Political order and one-party rule. Annual Review of Political Science 13: 123-143.

Maguire, D. 1995. Opposition movements and opposition parties: Equal partners or dependent relations in the struggle for power and reform? In The politics of social protest. Comparative perspectives on states and social movements, ed. J.C. Jenkins and B. Klandermans, 99-112. Minneapolis: University of Minnesota Press. 
March, L. 2009. Managing opposition in a hybrid regime: Just Russia and parastatal opposition. Slavic Review 68 (3): 504-527.

Mény, Y. 2008. France: The institutionalization of leadership. In Comparative European politics, ed. J.M. Colomer, 94-134. London: Routledge.

Niclauss, K. 1995. Das Parteiensystem der Bundesrepublik Deutschland. Paderborn: Schöningh.

Norton, P. 2008. Making sense of opposition. Journal of Legislative Studies 14 (1-2): 236-250.

Sartori, G. 1976. Parties and party systems. Cambridge: Cambridge University Press.

Schedler, A. 2013. The politics of uncertainty: Sustaining and subverting electoral authoritarianism. Oxford: Oxford University Press.

Skaaning, S.-E. 2020. Waves of autocratization and democratization: A critical note on conceptualization and measurement. Democratization 27 (8): 1533-1542.

Selçuk, O., D. Hekimci, and O. Erpul. 2019. The Erdoğanization of Turkish politics and the role of the opposition. Southeast European and Black Sea Studies 19 (4): 541-564.

Szulecki, K. 2019. Dissidents in communist central Europe: Human rights and the emergence of new transnational actors. Basingstoke: Palgrave.

Tertytchnaya, K. 2020. Protests and voter defections in electoral autocracies: Evidence from Russia. Comparative Political Studies 53 (12): 1926-1956.

Trantidis, A. 2017. Is government contestability an integral part of the definition of democracy? Politics 37 (1): 67-81.

Ufen, A. 2020. Opposition in transition: Pre-electoral coalitions and the 2018 electoral breakthrough in Malaysia. Democratization 27 (2): 167-184.

Whaman, M. 2014. Democratization and electoral turnovers in sub-Saharan Africa and beyond. Democratization 21 (2): 220-243.

York, E.A. 2020. Democratic Institutions under autocracy, Ph.D. thesis, Graduate School of Arts and Sciences, Columbia University.

Young, L.E. 2020. Who dissents? Self-efficacy and opposition action after state-sponsored election violence. Journal of Peace Research 57 (1): 62-76.

Zulianello, M. 2018. Anti-system parties revisited: Concept formation and guidelines for empirical research. Government and Opposition 53 (4): 653-681.

Publisher's Note Springer Nature remains neutral with regard to jurisdictional claims in published maps and institutional affiliations.

Ludger Helms (PhD, Heidelberg; venia legendi, Humboldt University, Berlin) is Professor of Political Science and Chair of Comparative Politics in the School of Social and Political Sciences, University of Innsbruck. He has held visiting positions at Harvard, Berkeley, Barnard, LSE, CEU, LUISS, Tokyo, and Gadjah Mada. He has widely published on comparative political institutions, political elites, and executive politics and leadership. Recent articles have appeared in such journals as The British Journal of Politics \& International Relations, Democratization, European Political Science Review, and Government and Opposition. He is the editor of Comparative Political Leadership (Palgrave, paperback 2016) and Parliamentary Opposition in Old and New Democracies (Routledge, paperback 2016), and a co-editor of The Oxford Handbook of Political Executives (Oxford University Press, 2020). 